\title{
Kernos
}

Revue internationale et pluridisciplinaire de religion grecque antique

13 | 2000

Varia

The Leases of Sacred Property at Mylasa: An Alimentary Scheme for the Gods

\section{Beate Dignas}

\section{(2) OpenEdition \\ Journals}

Electronic version

URL: http://journals.openedition.org/kernos/1299

DOI: 10.4000/kernos.1299

ISSN: 2034-7871

\section{Publisher}

Centre international d'étude de la religion grecque antique

Printed version

Date of publication: 1 January 2000

ISSN: 0776-3824

Electronic reference

Beate Dignas, «The Leases of Sacred Property at Mylasa: An Alimentary Scheme for the Gods », Kernos [Online], 13 | 2000, Online since 21 April 2011, connection on 01 May 2019. URL : http:// journals.openedition.org/kernos/1299; DOI : 10.4000/kernos.1299 
Kernos, 13 (2000), p. 117-126.

\section{The Leases of Sacred Property at Mylasa: An Alimentary Scheme for the Gods}

A complicated relationship existed between the local shrine at Carian Labraunda and the city of Mylasa in the second half of the third century B.C. The correspondence between several kings, the priests of Zeus, and the city attests to a long-lasting controversy between the city and the priests over the shrine and its revenues. Both authorities appealed to the local dynast and the Hellenistic kings, who acted as mediators and finally settled the whole affair. ${ }^{1}$ The events reveal an independent economic and political role of the sanctuary, and it would appear that the clash of interests between cult and city was neither confined to a transitional period nor overcome by the city's increasing control of the shrine.

However, Mylasa has yielded not only this fascinating dossier of epigraphic texts but also a large series of inscriptions which deal with the purchase and lease of properties by sanctuaries. Although these land-lease documents differ from the third-century letters in character and content, they have a common theme: "sacred finances and land". Many private landowners transferred some or all of their properties to a sanctuary but, peculiarly, immediately rented them back from the gods. ${ }^{2}$ Apart from the Delian temple accounts, the Carian land-lease documents represent our largest record of transactions concerning sacred properties. ${ }^{3}$ They come not only from the city of Mylasa itself but also from Olymus, Hydae, Sinuri and Labraunda. ${ }^{4}$ These four places were neighbouring communities and closely related to Mylasa.

1 Cf. J. CRAmpa, Labraunda. Swedish Excavations and Researches III 1. The Greek Inscriptions, Part I: 1-12 (Period of Olympicbus), Lund, 1969 (henceforth ILabraunda 1).

2 Cf. W. BLümel, IK 34. Die Inschriften von Mylasa I, Bonn, 1987 (henceforth IMylasa I), nos. 202-232; ID., IK 35. Die Inscbriften von Mylasa II (henceforth IMylasa II), nos. 802854; also ID., Neue Inscbriften aus Mylasa (1989-1991) mit Nacbträgen zu I.K. 34, in EA, 19 (1992), no. 217 B (cf. SEG 42 [1992], no. 999); ID., Inschriften aus Karien I, in EA, 25 (1995), nos. 7-25 (cf. SEG 45 [1995], nos. 1538-1555); there are many more unpublished texts found by Louis Robert.

3 Cf. D. BEHREND, Recbtshistoriscbe Betracbtungen zu den Pacbtdokumenten aus Mylasa und Olymos. Akten des VI. internationalen Kongresses für griechische und lateinische Epigraphik, Munich, 1972, p. 146 with note 4.

4 Gf. L. ROBERT, Le sanctuaire de Sinuri près de Mylasa, lère partie: les inscriptions grecques, Paris, 1945, nos. 11-15, 46-72; ILabraunda 1, nos. 6-8.; IMylasa II, nos. 802-854. 
Towards the end of the third century B.C., they were "absorbed" by sympoliteia and became subdivisions (demoi) of the greater Mylasean state. ${ }^{5}$

The texts have generally been dated to the second half of the second or even the beginning of the first century B.C. However, Reger recently suggested that they should be attributed to the beginning of the second or even the end of the third century B.C. His dating depends on his interpretation of Rhodian coinage and the assumption that cities of Caria called the Romans "common benefactors" as early as 188 B.C. ${ }^{6}$ Although Roman presence may not be directly visible, the central ruler had definitely changed for Mylasa by the middle of the second century B.C. In a contemporary honorary decree for

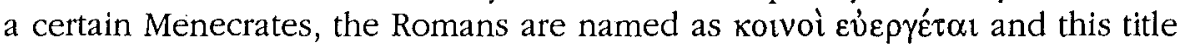
could have been used from 167 B.C. onwards, when the Romans declared Caria free from Rhodian rule. ${ }^{7}$ I find it problematic to date the leasing-documents twenty years earlier than this. ${ }^{8}$

\section{Characteristics of the Land-leases}

Neither the purchase, nor the lease of land by sanctuaries are surprising. Harpocration cites the grammarian Didymus, who explains the term $\mu$ í $\sigma \theta \omega \alpha$ as the equivalent to "revenues from temene", and as the means of meeting the expenses of sacrifice. ${ }^{9}$ Although it did occur, it was the exception that the renting out of the property of a god was forbidden. ${ }^{10}$ However, such leases were subject to special laws. An early inscription from Athens gives instructions to the arcbon basileus, who was in charge of the lease of sacred land, to turn to the law about sacred domains. ${ }^{11}$ Among other parallel evidence is the main Delian law on the lease of sacred property ( $i \varepsilon \rho \dot{\alpha}$

5 Cf. IMylasa II, nos. 901-910 (Hydai); no. 913 (Chalketor); IMylasa I, no. 102, with LIvy, XLV, 25 and PolyB., XXX, 5, 15 (Euromus); ILabraunda 1, nos. 3-5; IMylasa II, no. 863, 1. 3; RoBERT, op. cit. (n. 4), no. 93 (Sinuri).

6 Cf. G. REger, The Date of the Land-Transfer Texts of Mylasa in Karia, an unpublished paper given at the Annual meeting of the APA (1995) and likewise ID., Agriculture and the Rural Landscape of Hellenistic Mylasa (1996); this date makes the land-lease documents almost contemporary with the controversy over the sanctuary at Labraunda; for the conventional dating of the documents see IMylasa I, p. 74.

7 Cf. IMylasa I, p. 38; Ch. НАвІснт, Samiscbe Volksbescblïsse der bellenistischen Zeit, in MDAI(A), 72 (1957), p. 248; A. ERskine, The Romans as common benefactors, in Historia, 43 (1994), p. 70-87; J.-L. FerRary, Pbilbellénisme et impérialisme. Aspects idéologiques de la conquête romaine du monde bellénistique de la seconde guerre de Macédoine à la guerre contre Mitbridate, Rome, 1988, p. 129f., note 290.

8 However, Prof. Reger draws on unpublished material; I cannot refute his dating at this point.

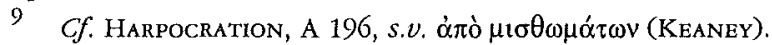

10 Cf. for example $I G \mathrm{II}^{2}, 1289$ (third century).

$11 I G \mathrm{I}^{3}, 84,1.5-7$ (cf. D. BeHREND, Attiscbe Pacbitukunden: Ein Beitrag zur Beschreibung der mistbosis nach den griechischen Inscbriften, Munich, 1970 [Vestigia, 12], no. 6). 


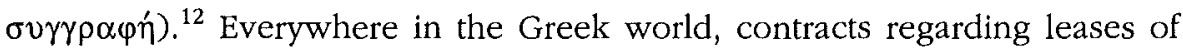
sacred land showed similar characteristics and wording. It is the combination of purchase and immediate hereditary lease to the former owner which singles out the documents from Mylasa.

The land-transfers consisted of several legal transactions, which are reflected by the following four types of documents: the decree by which a tribe resolved to buy an offered property $(\psi \eta \dot{\eta} \varphi(\sigma \mu \alpha)$, the document of pur-

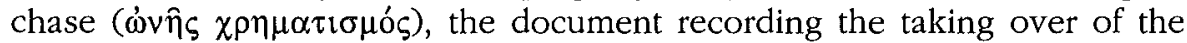
property by the commissioners ( $\varepsilon \mu \beta \alpha \sigma \iota \varsigma)$, and the contract fixing the hereditary lease ( $\mu \tau \sigma \theta \omega \sigma \varepsilon \omega \varsigma \chi \rho \eta \mu \alpha \tau \imath \sigma \mu o ́)$ ). The initial decree itself comprised the following proceedings: the commissioners reported to the assembly that a citizen was willing to sell a certain piece of land at a certain price, a citizen told the assembly that he or she was willing to rent these properties permanently, and the tribe decided to buy and lease out the property. ${ }^{13}$ The decree concluded with the instruction to inscribe the $\chi \rho \eta \mu \alpha \tau \tau \sigma \mu$ ó $\varsigma$ on the walls of the respective sanctuary. ${ }^{14}$ At Mylasa and in the surrounding villages special sub-divisions of the demos, not only the tribes but also so-called syngeneiai, administered the community and were responsible for the land-leases. Apart from this, the administrative procedures are comparable to those of other poleis. ${ }^{15}$

My examination of the inscriptions focuses on the overall purpose of the leases and the role of the gods in the transactions. It draws on existing studies of the Carian leases and on characteristics of leasing in the Greek world in general. ${ }^{16}$ Behrend carefully examined the legal aspects of purchase

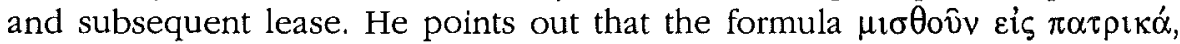
which was in use already in the third century B.C., has its equivalents in the

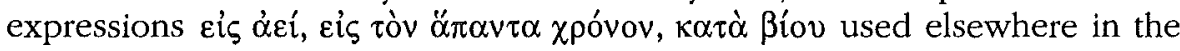

12 ID 503

13 Cf. IMylasa I, p. 70f.

14 Cf. BEHREND, art. cit. (n. 3), p. 158.

15 Cf. ROBERT, op. cit. (n. 4), p. 25-31; a syngeneia may be a subdivision of a pbyle or an institution preceding the tribe.

16 Apart from the works frequently referred to see for example M.H. JAMEson, The leasing of land in Rbamnous, in Studies in Attic Epigraphy, History, and Topograpby, Princeton, 1982 (Hesperia, suppl. 19), p. 66-74; J.H. KENT, The temple estates of Delos, Rbeneia and Mykonos, in Hesperia, 17 (1948), p. 243-338; Ph. Levenu (ed.), L'origine des richesses dépensées dans la ville antique, Actes du colloque organisé à Aix-en-Provence par l'U.E.R. d'Histoire, les 11 et 12 Mai 1984, Aix-en-Provence, 1985; R. MarTIN, Rapports entre les structures urbaines et les modes de division et d'exploitation du territoire, in M.I. Finley, Problèmes de la terre en Grèce ancienne, Paris, 1973, p. 97-112; R. OsBoRnE, Social and economic implications of the leasing of land and property in Classical and Hellenistic Greece, in Chiron, 18 (1988), p. 279-323; M.B. WALBANK, Leases of sacred properties in Attica, Parts 1-4, in Hesperia, 52 (1983), p. 100-135; p. 177-231; Part 5, Hesperia, 53 (1984), p. 361-368; a correction, Hesperia 54 (1985), p. 140. 
Greek world; leases from Ptolemaic Egypt show exactly the same phrase. ${ }^{17}$ Such a lease entailed that the supreme right of possession remained with the lessor (in other cases with the king), although the lessee received rights equivalent to those of an owner. This makes the leases at Mylasa a combination of the usual land leasing mechanisms and the royal practice of giving out land $\varepsilon i \varsigma \pi \alpha \tau \rho \iota \kappa \alpha$. The sanctuary gave up the right of managing the property but enjoyed a regular rent and created a strong bond between the god and the lessee. The lessee's strong position derived from the fact that the lease was hereditary and could even be transferred to a third person, a process which was called $\pi \alpha \rho \alpha \chi \omega \dot{\rho} \eta \sigma \iota c$. Although the cases resemble one another, each lease shows special features.

\section{Why such a Large Number of Leases?}

Scholars find it difficult to explain the existence of the series as a whole: why was an apparently large proportion of the arable land of Mylasa in the possession of sanctuaries? Why did such an enormous number of transactions take place within a short period of time ${ }^{18}$ One might interpret the transactions simply as the most practical way of living for both sides: while the sanctuary preferred low-risk investments in landed property, the former owners, who continued to farm the land, paid only a modest rent and were able to spend capital on other investments. ${ }^{19}$ This explanation, however, does not account for the sudden appearance of so many transactions; unless we assume a period of extraordinary prosperity of Carian sanctuaries.

In what follows, I want to refute current views briefly and then set out my own hypothesis. Chance of transmission or a change in the way of recording leases cannot be the only reasons. ${ }^{20}$ Undoubtedly, there was an exceptional interest of landowners in selling their lands to the gods, and these were exceptionally eager to invest in land. It has been suggested that the reason for this eagerness was the "fear of pirates". ${ }^{21}$ But, if Mylasa suffered from piracy ${ }^{22}$, this would encourage every landowner to keep landed

17 Cf. BeHrend, art. cit. (n. 3), p. 148-153.

18 For reasons suggested see BeHREND, art. cit. (n. 3), p. 146-148; W. Buümel, IMylasa I, on nos. 202-232.

19 RIJG, p. 272.

$20 C f$. BEHREND, art. cit., p. 146, "dann müßten riesige Tempeldomänen entstanden sein, von denen uns nichts bekannt ist".

21 Cf. T.R.S. Broughton, Roman Asia Minor, in T. Frank (ed.), ESAR IV, p. 561; R. BOGAERT, Banques et banquiers dans les cités grecques, Leiden, 1968, p. 270; BEHREND, art. cit. (n. 3), p. 147.

22 Mylasa was far away from the sea but the Hellenistic decrees which award Mylasa asylia indicate that the city or its territory did indeed suffer from raids; see K.J. RIGSBY, Asylia. Territorial Inviolability in the Hellenistic World, Berkeley, 1996, nos. 187-209 (cf. IMylasa II, nos. 641-659, 720; SEG 39 [1989], no. 1127; SEG 42 [1992], nos. 1003-1006). 
property. Private landowners who sold their property would also need to protect considerable amounts of money. ${ }^{23}$ I therefore want to dismiss the reason "piracy" as the decisive factor. What about political reasons? The gods' landed property certainly formed an important part of the patterns of land-holding throughout Caria. Although one must not underestimate the social and political implications of changes in these patterns, I do not think that political motives triggered the sales. As the gods' ownership of widely scattered plots of land was a general feature, conclusions about the integration or political influence of the lessees of sacred land are problematic. ${ }^{24}$

Were there economic advantages resulting from placing land under the

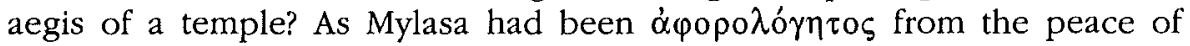
Apameia at the latest, tax exemptions would not have made religious centres exceptional landlords. ${ }^{25}$ However, we might still suspect advantages to do with obligations levied by the city. The leases of sacred property show an exceptionally low rate of interest, that is ca. $4 \%$ of the purchase price; ${ }^{26}$ but the calculation and interpretation of such a rate of interest are problematic and often ill founded; we need evidence that enables us to compare the figures with rates of interest concerning land that is not qualified as sacred. I propose to draw on an inscription from Sinuri, which has not received much attention from scholars. ${ }^{27}$ The basic situation described in the document has analogies at Mylasa itself, at Telmessus, Athens and Delphi: ${ }^{28}$ at Sinuri, the

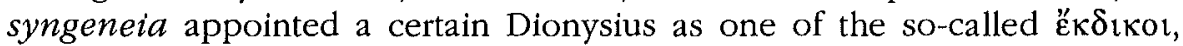
whose task was to operate against people trying to encroach upon the sacred domain of the god. ${ }^{29}$ As soon as Dionysius and his colleagues had managed to restore the "̈ $\gamma \gamma \alpha 1 \alpha$ for the god and the syngeneia, they turned to another matter. Certain people were accused of harming the syngeneia and the god by claiming a lower phoros - simply because they lived on sacred

23 Cf. BogaER', op. cit. (n. 21), p. 270.

24 Reger, who is currently working on a new publication of this dossier, including new land-lease texts, believes that the land-leases are closely linked with the established sympoliteia of Mylasa and the smaller communities; he argues that as a consequence, the social position of the wealthy élite of the smaller towns was threatened and that the new land-holding patterns resulted in a patchwork of properties which advanced the integration of the smaller states; I have my doubts about this explanation, but it is inappropriate to elaborate these doubts in advance of the full publication of Professor Reger.

25 Behrend, art. cit. (n. 3), p. 148, refers to Livy, XXXVIII, 39, 8 and PolyB., XXI, 46.

26 Cf. RIJG, p. 273; IMylasa I, p. 31; WALBANK, art. cit. (n. 16), p. 225.

$27 C f$. RoBert, op. cit. (n. 4), no. 11; Robert distinguishes between "procès relatifs aux domaines du dieu" (here we find no, 11), "commissaires pour l'achat de terrains", and "domaines du dieu".

28 Cf. ibid., p. 36; IMylasa I, no. 132, 1. 4-6 (sacred land of Aphrodite had been misappropriated); Recueil, no. 459, 10 (Telmessus); $I G \mathrm{II}^{2}, 1035 ;$ Syll. ${ }^{3}, 826$.

29 Cf. Robert, op. cit. (n. 4), no. 11, 1. 6-9. 
land. ${ }^{30}$ Unfortunately, the inscription remains enigmatic but the expectation of a low interest rate explains why people were generally interested in leasing land from the gods. ${ }^{31}$ I accept this as the reason why private land-owners would consider selling their property to gods.

However, why was it so cheap to rent from the gods? Were the sanctuaries welfare institutions? There is no indication that the citizens of Mylasa and its neighbouring small communities went through a phase of economic hardship so that they turned to the local sanctuaries for help, that is to free them from debt and mortgage. As far as I can see, none of the estates carried a mortgage. Nevertheless, I would argue that economic reasons were indeed responsible for the programmatic land-transfers - but we have to emphasise the economic needs of the other side involved, the sanctuaries. Recently, Merkelbach suggested that the transformation of so many private estates into temple land reflected a fundamentalist religious attitude and intended to revive the old Carian "Tempelwirtschaft" of premonetary times. Accordingly, a combination of "piety" and "atavism" was responsible for the programmatic changes in the pattern of land-holding, which were reversed as Caria became part of the Roman province of Asia ${ }^{32}$ Although neither of the two abstract concepts provide a satisfactory explanation, Merkelbach's focus on the sanctuaries leads us in the right direction. Moreover, he correctly points to the fact that the leases reflect programmatic activities, that private landowners must have been actively and publicly encouraged to sell their land.

\section{An Alimentary Scheme for Sanctuaries}

I suggest that the Mylasean land-transfers are comparable to the Trajanic alimentary scheme. ${ }^{33}$ This system of government aid, which provided for the support of children in towns all over Italy, was financed by government

30 Cf. ibid., 1. 9-14; surprisingly, the offenders were treated with polite discretion. They were not named in the inscription but referred to vaguely as $\tau$ ıvéc. It is not necessarily a "positive" event or setting which could lead to sudden financial operations of temples.

31 How should we imagine the situation? How can Dionysius act on behalf of the god and of the syngeneia? If there were no distinction between sacred and public funds, why is there a different rent? $C f$. RoBert, op. cit. (n. 4), p. 39.

32 Cf. R. Merkelbach, Das Repertorium der Inschriften von Mylasa. Zu Th. DrewBears Rezension von I.K. 34 (W. Blümel), mit einer Hypotbese über die Mylaseer Pachturkunden, in ZPE, 101 (1994), p. 306; cf. SEG 44 (1994), no. 907; similarly already A. Laumonier, Les cultes indigènes en Carie, Paris, 1958, p. 109, "Cette reprise des terres par les dieux est un curieux retour... à un état de choses très ancien... selon une sorte d'étatisme ou de communisme théocratique".

33 For the following and further details $c f$. R. DunCaN-Jones, The Economy of the Roman Empire. Quantitative Studies, Cambridge, $1974^{2}$, p. 288-319; G. Woolf, Food, poverty and patronage. The significance of the epigrapby of the Roman alimentary schemes in early imperial Italy, in PBSR, 58 (1990), p. 197-228; D. JoHNSTON, Munificence and municipia: bequests to towns in classical Roman law, in JRS, 75 (1985), p. 105-125. 
grants placed with landowners in the districts; each landowner who accepted a loan received a sum worth a certain percentage of the stated value of his land, on which he had to pay the city interest, which formed the income from which the children were supported. Rich information about the loans has come down to us through inscriptions from the towns of Veleia and Ligures Baebiani. ${ }^{34}$ They illustrate that the farming out of loans to private landowners was the only and most effective means for securing a permanent revenue of a sufficient scale. ${ }^{35}$ Being a perpetual foundation, they were selfcontained and protected the dependants from suspension of payment in years of deficit. In the light of this clear advantage - and in order to attract landowners to participate - the interest-rate on the loans could be and was a little lower than the rate mentioned as the normal return on landed investments. However, it was not the chief purpose of the scheme to provide landowners with cheap credit. On the contrary, it would appear that participation fell under the category of civic munera. ${ }^{36}$

Like the Roman alimentary loans at the beginning of the second century A.D., the Mylasean land-transfers constituted a scheme designed to guarantee regular, reliable income for earmarked purposes. In this case, the Mylasean civic and religious authorities tried to solve a long-term, structural problem that many communities and their sanctuaries faced: very often the high costs of running the cults were not met by the existing regular sacred revenues. Sacred funds were easily diverted and treasuries highly unstable or spent on exceptional expenses. Sacred property had probably been gradually diminished because private landowners encroached on the estates of the gods. A good way to solve the problem and at the same time to free the community from an extra burden was to increase the land leased out for the gods.

Let us return to the texts. A few documents tell us about the purpose of the operations from the "gods' point of view". The investment is made so that "the gods will enjoy the revenues from sums bequeathed to them for all times". ${ }^{37}$ When in 240 B.C. the governor of Seleucus II, Olympichus, announced a dedication of lands to Zeus Osogoa, he referred to precisely the same purpose. ${ }^{38}$ He suggested that the people of Mylasa lease out the dedi-

34 Cf. CIL XI 1147 (= E.M. SMaLlwood [ed.], Documents Illustrating the Principates of Gaius, Claudius and Nero, Cambridge, 1967, no, 436) and CIL IX, 1455.

35 Duncan-Jones, op. cit. (n. 33), p. 296, compares the scheme with private foundations.

36 Cf. ibid., 295 note 5 with references; DunCan-Jones, p. 300, finds it "highly doubtful whether the alimentary loans could offer any real economic attraction to borrowers, except those who needed to be bailed out of debt."; for participation as a civic obligation see ibid., p. 308-310.

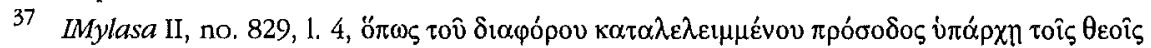

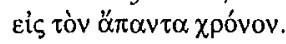

38 Cf. ILabraunda 1, no. 8. 
cated properties on a hereditary basis at an interest of $5 \%$ so that $\dot{\eta} \dot{\alpha} \pi \dot{0}$

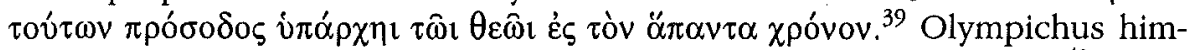
self will be the future lessee so that his grant works like a foundation. ${ }^{40}$

Sanctuaries were well-advised not only to draw revenues from existing landed property, but also to acquire new estates as the best way of investing sacred funds. The following statements can be found in the documents: "As land is for sale, it is the appropriate thing to buy those properties for the

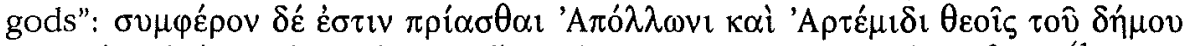

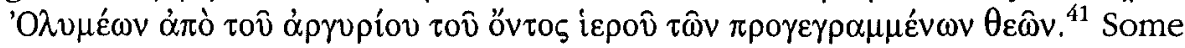

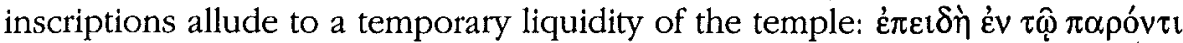

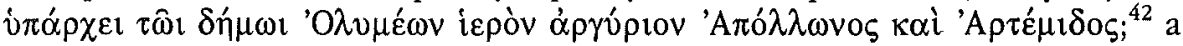
legacy or exceptional euergetism might have been responsible for the

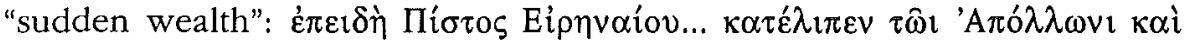

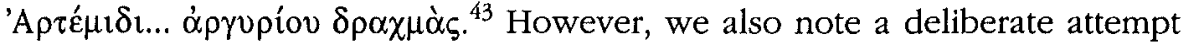
to purchase property on behalf of a temple, although the full sum is not immediately available. In one case, three priests, men of high rank, advance the money and sign as responsible for the purchase. ${ }^{44}$ At Sinuri, the commissioners report that they could not find an appropriate territory for the amount they received for a purchase. ${ }^{45}$ The leases were therefore not only a sensible investment of unused sacred funds but a necessary means to guarantee regular sacred revenues. Given this purpose, the enigmatic inscription from Sinuri becomes clearer: it illustrates the effort to make the sanctuary's status as landlord as permanent as possible. The lessee may change, as long as the regular revenues are guaranteed for the shrine. ${ }^{46}$

That the focus of the programme lay on the sanctuaries and that the landowners were not desperate to sell can be seen in the case of the local aristocrat Diodotus, son of Demetrius, who held a farm in joint ownership with Cleito, the daughter of Hybreas and priestess of Apollo and Artemis; while Demetrius sold his half to Zeus of the Otorkondeis, the priestess retained hers. ${ }^{47}$ It is unlikely that half of the property was an economic burden while the other flourished. It is also understandable why only Demetrius' half was involved in the sale. The priestess would not sell her property to another

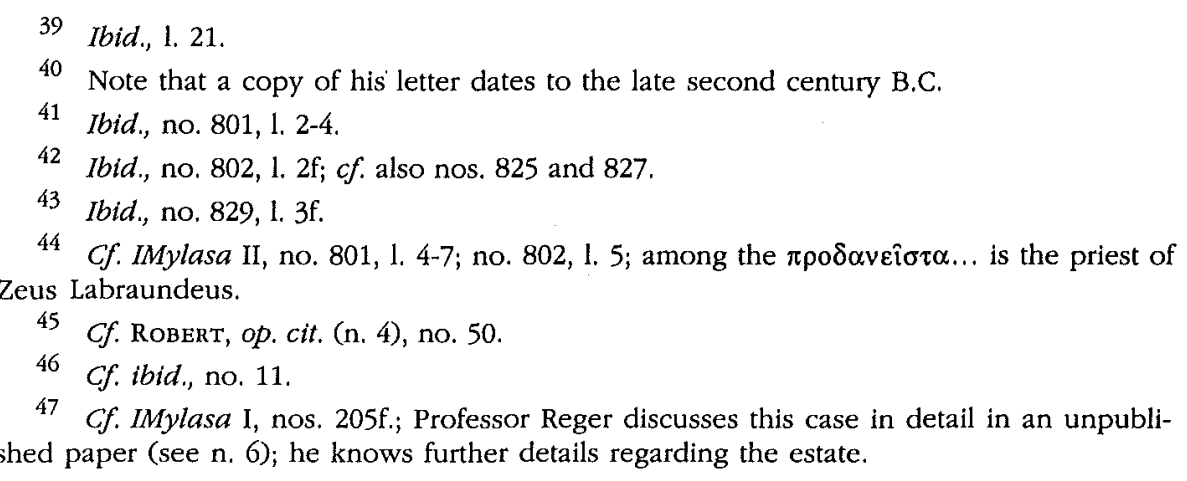


deity, nor would there be any need for her to take part in the scheme; her half might anyway have yielded income for the gods. Neither a "fundamentalist religious attitude", nor a revived "Tempelwirtschaft" are the right labels for the Mylasean land-lease documents. They derived rather from the experience that the gods needed a guaranteed income and that only the revenues of sacred land could provide this.

\section{Co-operation instead of Controversy}

The private landowners who gave up their estates in order to become lessees of Mylasean deities must have been encouraged by the civic authorities. Obviously, the syngeneia or demes negotiated the purchase and lease of the lands on behalf of the sanctuaries, and these civic institutions almost functioned as buyer and lessor. Their dominant role is reflected in the title of

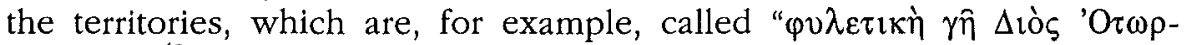
кov $\delta \dot{\varepsilon} \omega v ",{ }^{48}$ Nevertheless, the frequent emphasis on both the gods and the sacred funds must not be ignored, and twofold expressions like $\tau \hat{\omega} \iota$ $\theta \varepsilon \hat{\omega} \mathrm{\imath} \kappa \alpha \grave{i}$

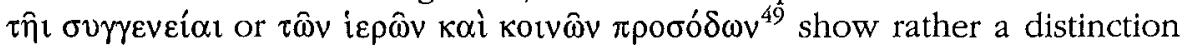
of funds and revenues than that they were interchangeable. Moreover, my interpretation has shown that the whole record is based on the fact that it was the gods' income that was at stake.

I wonder how the phenomenon relates to the controversy between the priests of Labraunda and the city of Mylasa which took place some time before the leases started to appear. ${ }^{50}$ As far as we can see from the preserved texts, Zeus Labraundeus was not involved in many transactions, but land was also acquired in his name; his estates appear frequently when the boundaries of sold lands are described. If Mylasa had just "recovered" from the serious controversy with the priests at Labraunda, the demos would have hesitated to develop a scheme which increased sacred land dramatically. ${ }^{51}$ Although the authorities freed themselves from additional support for the cults (and the default of such support was one of the main issues in the controversy), they would not have risked that ambitious priests like Korris should exploit the situation and claim extra revenues. Some decades later, however, the relationship appears in a very different light, the atmosphere of

48 IMylasa I, no. 214, 1. 14; cff. also IMylasa II, nos. 802 and 819 , for the phrase غ̇лєı $\delta \dot{\eta}$

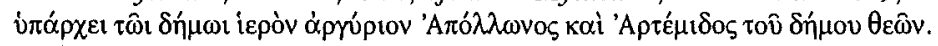

$49 C f$. ROBERT, op. cit. (n. 4), nos. 10f. and 14f.; Robert simply concludes, "Les affaires du dieu et celles de la syngeneia sont les mêmes"; W. BLüMEL, IMylasa II, p. 74, "Er [Zeus Otorkondeonl hatte ausgedehnten Grundbesitz, der natürlich für alle praktischen Zwecke Grundbesitz der Phyle war".

50 Obviously, the "how long before" depends on the dating of the land-leases; a corpus of new texts from Mylasa will hopefully allow for more certainty.

51 Cf. IMylasa I, no. 102; the priest of Zeus Labraundeus is also the secretary of the city. 
mutual suspicion had given way to a natural co-operation. In the second century B.C., Mylasa and the local sanctuaries had not merged identity but shared common interests.

My interpretation of the land-leases makes it clear that transactions of this kind were a structural necessity for Greek sanctuaries and must have taken place in most communities. The following passage, which is taken from a Rhodian inscription, illustrates a comparable context nicely: $\dot{\varepsilon} \pi \varepsilon 1 \delta \grave{\eta}$

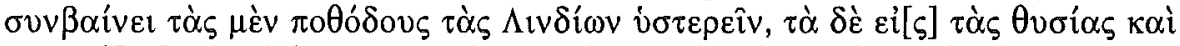

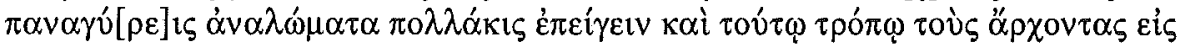

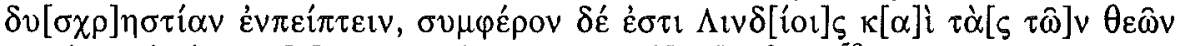

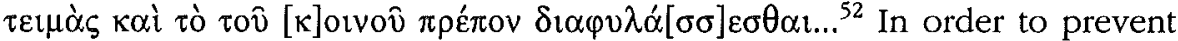
officials from diverting sacred funds, the Lindians tried to find a solution that dealt with an acute financial crisis (particularly with regard to sacred matters) and furthered both the gods and the community. While Lindos and many other cities found their solution in ad hoc measures such as subscriptions or other forms of encouraged euergetism, Mylasa came up with the idea of developing a special scheme, and it thus produced an exceptional epigraphic record. ${ }^{53}$

To sum up the evidence in one sentence: Mylasa is a unique solution to a common problem. The following remains to be stated: the fact that the gods were the beneficiaries of an "alimentary scheme" does not deny the notion of sacred wealth. After all, the sanctuaries bougbt the large number of estates, and by the end of the second century a vast amount of land around Mylasa must have been sacred. However, there was a particular need to guard the privileges and property of the gods. These were always in danger, and the situation of temple finances oscillated between burden and blessing.

Beate Dignas.

University of Michigan

Department of History

1029 Tisch Hall

Ann Arbor, Michigan 48109-1003

52 F. SoKolowski, LSCG Suppl. 90, 1. 5-9 (cf. Ch. BLINKEnBerg, Lindos. Fouilles de l'acropole, 1902-1924 II. Inscriptions, Berlin, 1941, no. 419; L. MigeotTE, Les souscriptions publiques dans les cités grecques, Geneva, 1992, no. 41).

53 Though a different and very complex phenomenon, the "sales of priesthoods" in cities of Asia Minor and the eastern Aegean would appear to be another answer to the same problem. 